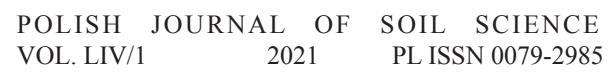

DOI: $10.17951 / \mathrm{pjss} / 2021.54 .1 .89$

\title{
JOZEF KOBZA*
}

\section{ARSENIC IN AGRICULTURAL SOILS OF SLOVAKIA}

Abstract. The article presents the current distribution of arsenic in agricultural soils of Slovakia. The current concentration of arsenic (extracted with aqua regia) was measured and evaluated based on 318 monitoring sites of national soil monitoring system in Slovakia. Based on the obtained results, one can state that the average content of arsenic is lower than the valid hygienic limit for arsenic (25 mg. $\left.\mathrm{kg}^{-1}\right)$ for predominated sandy-loamy and loamy soils in Slovakia. Increased values of arsenic were determined only for the Horná - Upper Nitra region (anthropogenic impact) - $24.5 \mathrm{mg} \cdot \mathrm{kg}^{-1}$ and for the Stredný - Central Spiš region (mixed anthrophogenic and geogenic impact) - $129.5 \mathrm{mg} \cdot \mathrm{kg}^{-1}$. These regions belong to the most arsenic-affected regions in Slovakia, where the content of bioavailable forms of arsenic is also increased in the range of $0.013-0.997 \mathrm{mg} \cdot \mathrm{kg}^{-1}$. The hygienic limit for bioavailable arsenic in soils of Slovakia is 0.4 $\mathrm{mg} . \mathrm{kg}^{-1}$. Finally, there is a serious risk of arsenic transport from soil into the plants and food chain especially in case of acid soils. A higher risk of As presence seems to be in anthropogenically affected soils.

Keywords: arsenic, soil contamination, soil monitoring system, agricultural soils, Slovakia

* National Agricultural and Food Centre - Soil Science and Conservation Research Institute in Bratislava; regional working place Banská Bystrica and the Faculty of Natural Sciences of Matej Bel University, Banská Bystrica, Slovakia, e-mail: jozef.kobza@nppc.sk 


\section{INTRODUCTION}

Soils contaminated with arsenic (As) are relatively frequent. The contamination is connected with the coal combustion (e.g. Horná - Upper Nitra), where the content of As in Nováky coal mine ranges from 800 to $1,530 \mathrm{mg} \cdot \mathrm{kg}^{-1}$ (Verbich 1998), as well as with metal processing and pesticides utilization (Čurlík and Šefčík 1999). Much greater attention is paid to arsenic transport on the surface or in groundwater that subsequently leads to stream and bottom sediments contamination in rivers, water reservoirs and lakes. This transport can influence also agricultural land and soils - above all alluvial plains in the following soil sequence Fluvisols - Gleyic Fluvisols - Gleysols (FAO 2014). An important natural source of arsenic are mostly sulfidic minerals (Table 1). In Slovakia, the most frequent mineral is arzenopyrite (FeAsS).

Table 1. Occurence of significant As minerals in soils of Slovakia (Zsolnai 2011)

\begin{tabular}{ccc}
\hline Minerals & Chemical formula & Origin \\
\hline Arzenopyrite & $\mathrm{FeAsS}$ & hydrothermal, metamorphic \\
\hline Niccolite & $\mathrm{NiAs}$ & hydrothermal, magmatic \\
\hline Geocronite & $5 \mathrm{PbS} . A s S b S_{3}$ & hydrothermal \\
\hline Enargite & $\mathrm{Cu}_{3} \mathrm{AsS}_{4}$ & hydrothermal \\
\hline Gersdorffite & $\mathrm{NiAsS}$ & hydrothermal \\
\hline Cobaltinen & $\mathrm{CoAsS}$ & hydrothermal and metamorphic \\
\hline Auripigment & $\mathrm{As}_{2} \mathrm{~S}_{3}$ & hydrothermal \\
\hline Realgar & $\mathrm{As}_{4} \mathrm{~S}_{4}$ & secondary in oxidation zone of Cu deposit \\
\hline Euchroite & $\mathrm{Cu}_{2}\left(\mathrm{AsO}_{4}\right)(\mathrm{OH}) \cdot 3 \mathrm{H}_{2} \mathrm{O}$ & secondary in Cu deposits \\
\hline Clinoklase & $\mathrm{Cu}_{3}\left(\mathrm{AsO}_{4}\right)(\mathrm{OH})_{3}$ & product of As oxidation in minerals \\
\hline Arsenolite & $\mathrm{As}_{2} \mathrm{O}_{3}$ &
\end{tabular}

An average content of arsenic in world soils is 10 mg. $\mathrm{kg}^{-1}$ (Čurlík 2011), in the USA it is $7.2 \mathrm{mg} \cdot \mathrm{kg}^{-1}$ (Adriano 2001) and in case of European soils, an average content of arsenic in topsoil is $7.03 \mathrm{mg} \cdot \mathrm{kg}^{-1}$, whereas in subsoil it is $6.02 \mathrm{mg} \cdot \mathrm{kg}^{-1}$ (de Vos et al. 2006). In some mining areas, the content of arsenic can be very high (10,000-20,000 mg.kg-1 - Smith et al. 1998). Although As minerals are soluble, their migration is limited by the influence of strong sorption by clay, hydroxides, oxides and organic matter (Čurlík and Šefč́i 1999). In addition, the risk of its leaching into the groundwater (as well as its bioavailability) is relatively low (Kobza et al. 2007). Behaviour of As is similar to that of phoshorus and characterises with a strong fixation in the surface layer of soil, which can be temporarly evaluated as a positive hygienic ability of soil but, on the other hand, there are created conditions for increased accumulation of As in soil, which could be rather problematic in the future (Kobza et al. 2019a). In addition, As creates volatile 
compounds which allows remote wind transmission on the soil by dry or even wet deposition (especially anthropogenic influence by industry). Content of As in these depositions mostly ranges from 800 to $900 \mathrm{mg} \cdot \mathrm{kg}^{-1}$ (Čurlík 2004).

In the regions characterized by geochemical anomalies, the content of As in the soil increases with depth where the highest content of As is found in the deeper part of the soil profile. Practically, the content of As is high to very high in all soil profiles in this case. By the weathering and oxidation of As, ores (most frequently arsenopyrite FeAsS) can penetrate arsenic oxidic compounds: $\mathrm{H}_{3} \mathrm{AsO}_{3}^{\circ}, \mathrm{H}_{2} \mathrm{AsO}_{3}$, $\mathrm{HAsO}_{3}{ }^{2-}, \mathrm{AsO}_{3}{ }^{3-}, \mathrm{H}_{3} \mathrm{AsO}_{4}{ }^{\circ}, \mathrm{H}_{2} \mathrm{AsO}_{4}{ }^{2-}$ and $\mathrm{AsO}_{4}{ }^{3-}$. Increased As concentration is often measurable in mountainous and submountainous regions mostly on crystalline and volcanic rocks and also particularly in soils on calcium carbonate rocks Cambisols and Rendzic Leptosols (FAO 2014, Kobza 2011, Kobza et al. 2019a).

As concentration in soils depends on its oxidation state. In reducing soil conditions, As methylation and alkylation conducted by microbial activities, takes place. Methylation can influence higher As migration and fluxes among the environmental compartments (Fergusson 1990, Kabata-Pendias and Pendias 1992).

Based on described factors in soil, one can state that the concentration range and spatial distribution of As are very heterogenous and show relation to natural and anthropogene contamination (Čurlík and Šefč́́k 1999). Oats and tobacco are among the plants which can accumulate arsenic if they are cultivated especially by arsenic-based pesticides (Melicherčík and Melicherčíková 2010). In addition, the residues of As from fertilizers, pesticides, emissions, sewage sludge, bottom sediments, etc. could be accumulated in the surface horizon of agricultural soils (Berrow and Burridge 1980). Natural and anthropogenic impact of arsenic affects the current As content of the soil which is evaluated in this paper.

\section{MATERIALS AND METHODS}

Arsenic was measured in topsoil $(0-10 \mathrm{~cm})$ and subsoil $(35-45 \mathrm{~cm})$ of agricultural soils (318 monitoring sites of the national soil monitoring network), including the main soil types in Slovakia (Fig. 1). There were analysed and statistically evaluated the main soil types - 29 soil profiles of Chernozems, 31 soil profiles of Luvisols, 36 soil profiles of Fluvisols, 89 soil profiles of Cambisols, 18 soil profiles of Rendzic Leptosols and 8 soil profiles of Regosols from the national soil monitoring network.

In addition, the regions which are most vulnerable to arsenic (Horná Upper Nitra and Stredný - Central Spiš) were also sampled (36 soil samples in Horná - Upper Nitra and 14 soil samples in Stredný - Central Spiš have been taken in the agricultural land) and analysed. The soil samples were air-dried in laboratory. After drying, the samples were crushed, homogenized and drysieved through a $0.125-\mathrm{mm}$ sieve. 


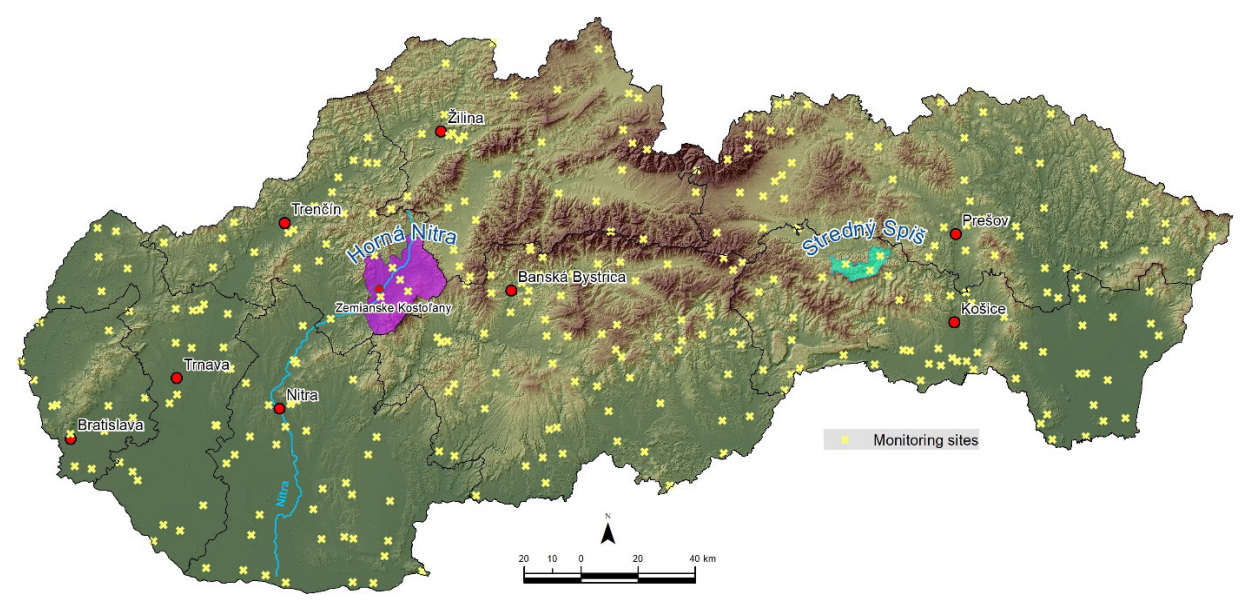

Fig. 1. Soil monitoring network in Slovakia with regions affected by As (Horná - Upper Nitra and Stredný - Central Spiš)

Arsenic was extracted with aqua regia using microwave radiation on atomic absorption spectrophotometer (AAS) according to Act No. 220/2004 (MP SR 2004) and Regulation No. 59/2013 (MPRV SR 2013) on protection and agricultural land use. In monitoring sites where the content of As exceeds the valid hygienic limit specified with aqua regia for Slovakia $\left(25 \mathrm{mg} . \mathrm{kg}^{-1}\right.$ for predominated sandy-loamy and loamy soils) (MPRV SR 2013), there were also determined the bioavailable forms of As extracted with $1 \mathrm{M} \mathrm{NH}_{4} \mathrm{NO}_{3}$ and using AAS. The measurement of As is performed with the help of electrothermal atomization in the optical axis of the instrument by dosing the sample into a graphite cuvette. Methodical and analytical procedures regarding the issue of As are described in more detail by Kobza et al. (2011). Chemical procedures with the use of arsenic were performed in the chemical laboratory of the National Agricultural and Food Centre - Soil Science and Conservation Research Institute in Bratislava. Soil monitoring network map (Fig. 1) and mathematical/statistical evaluation of obtained data have been evaluated in GIS.

\section{RESULTS AND DISCUSSION}

The current concentration of As in agricultural soils in Slovakia is given in Table 2. The mean values of As do not exceed the valid hygienic limit for Slovakia neither in topsoil nor in subsoil (MP SR 2004, MPRV SR 2013). In terms of the measured values of As, coefficient of variation is rather high $-61.35 \%$ in topsoil and $65.26 \%$ in subsoil. High variability of As in soils of Bangladesh was also observed - from $34.85 \%$ to $69.36 \%$ (Kabir et al. 2016). It was also confirmed that variability of As is similar in all soil profiles of agricultural soils 
in Slovakia (Čurlík and Šefčík 1999). Arithmetic mean and median values are lower than the valid hygienic limit for soils in Slovakia (Table 2) (MPRV SR 2013). Concentration of As in soil depends on geology and soil type (Čurlík and Šefćík 1999, de Vos et al. 2006). Distribution of As (extracted with aqua regia) in predominated soil types (in topsoil) of Slovakia is given in Table 3.

Table 2. Basic statistical indicators of As (mg.kg-1) extracted with aqua regia in agricultural soils of Slovakia

\begin{tabular}{cccccccc}
\hline \multirow{2}{*}{ Depth in $\mathrm{cm}$} & \multicolumn{7}{c}{ Basic statistical indicators } \\
\cline { 2 - 8 } & $\mathrm{n}$ & $\mathrm{X}_{\min }$ & $\mathrm{X}_{\max }$ & $\mathrm{X}$ & median & $\mathrm{Sd}$ & $\mathrm{CV}(\%)$ \\
\hline $0-10$ & 318 & 2.66 & 51.70 & 10.16 & 8.91 & 7.14 & 61.35 \\
\hline $34-45$ & 318 & 2.18 & 39.33 & 9.56 & 8.61 & 6.40 & 65.26 \\
\hline
\end{tabular}

Explanations: $\mathrm{n}$ - frequency, $\mathrm{X}_{\min }-$ minimum value, $\mathrm{X}_{\max }-$ maximum value, $\mathrm{X}$ - arithmetic mean, $\mathrm{Sd}$ - standard deviation, $\mathrm{CV}$ - coefficient of variation

Table 3. Basic statistical indicators of As (mg.kg-1) extracted with aqua regia in topsoil $(0-10 \mathrm{~cm})$ of the main soil types of Slovakia

\begin{tabular}{cccccccc}
\hline \multirow{2}{*}{ Soils } & \multicolumn{7}{c}{ Basic statistical indicators } \\
\cline { 2 - 8 } & $\mathrm{n}$ & $\mathrm{X}_{\min }$ & $\mathrm{X}_{\max }$ & $\mathrm{X}$ & median & $\mathrm{Sd}$ & $\mathrm{CV}(\%)$ \\
\hline 1 & 29 & 4.40 & 26.50 & 10.00 & 9.30 & 3.90 & 38.6 \\
\hline 2 & 31 & 3.13 & 15.50 & 9.22 & 9.40 & 2.45 & 26.54 \\
\hline 3 & 36 & 2.50 & 34.60 & 10.80 & 9.60 & 6.00 & 55.4 \\
\hline 4 & 89 & 1.00 & 223.00 & 14.81 & 9.99 & 2.44 & 171.77 \\
\hline 5 & 18 & 2.32 & 28.84 & 13.11 & 11.93 & 6.90 & 52.63 \\
\hline 6 & 8 & 1.54 & 4.79 & 3.37 & 3.51 & 1.07 & 31.93 \\
\hline
\end{tabular}

Explanations: 1 - Chernozems, 2 - Luvisols, 3 -Fluvisols, 4 - Cambisols, 5 - Rendzic Leptosols, 6 - Regosols, $\mathrm{n}$ - frequency, $\mathrm{X}_{\min }-$ minimum value, $\mathrm{X}_{\max }-$ maximum value, $\mathrm{X}$ - arithmetic mean, $\mathrm{Sd}$ - standard deviation, $\mathrm{CV}$ - coefficient of variation

Based on the obtained results, average values of As in main soil types is lower than valid hygienic limit for Slovakia (MP SR 2004, MPRV SR 2013). An increased average value of As was determined in Cambisols with the highest maximum value ( $223 \mathrm{mg} \cdot \mathrm{kg}^{-1}$ ), which is caused by the occurrence of these soils in mountainous and submountainous regions affected often by the occurrence of geochemical anomalies (especially Cambisols situated on crystalline and volcanic rocks). Therefore, the content of As is rather variable in Cambisols (coefficient of variation is $171.77 \%$ ) - Table 3. The lowest content of As was determined in Regosols. These soils are characterised by the lowest content of all risk elements, which has already been confirmed in some previous works (Berghofer et al. 1997, Wilcke et al. 2005). Regosols are characterised by the shallow A horizon with: the low content of humus $(<1 \%)$, low quality $\left(\mathrm{C}_{\mathrm{HA}} / \mathrm{C}_{\mathrm{FA}}<1\right)$ and low sorption capacity (Kobza et al. 2019a). Described Regosols are situated on quarzite eolic sands in 
the western part of Slovakia with average $\mathrm{pH} / \mathrm{KCl} 4.89$ (Kobza et al. 2019a). The process of acidification can accelerate the migration of As in the soil profile with potential contamination of groundwater. Arsenic is present in soils mostly as $\mathrm{As}^{5+}$, in reduction environment change into $\mathrm{As}^{3+}$ form which can be easily transported into the deeper part of the soil profile as well as to groundwater (Čurlík 2011). Higher concentrations of As are found in alluvial soils and in soils rich in organic matter (Shacklette and Boerngen 1984). Based on our results, concentration of As in Fluvisols, Chernozems, Rendzic Leptosols and Cambisols oscilates between 10 and $14.81 \mathrm{mg} \cdot \mathrm{kg}^{-1}$ (Table 3), except Regosols (3.37 mg. $\mathrm{kg}^{-1}$ ). This is consistent with Čurlík and Šefč́ik (1999) who state that the background concentrations of As in "natural soils" are generally low, and for various soil types, vary from 1 to 95 mg.kg-1 . Distribution of As (extracted with aqua regia) in the main soil types (in subsoil) of Slovakia is given in Table 4.

The mean values of As in subsoil are similar as in topsoil of main soil types in Slovakia (from 3.30 to $12.55 \mathrm{mg} \cdot \mathrm{kg}^{-1}$ ) (Table 4). The highest variability of As was measured in Cambisols $(\mathrm{CV}=115.57 \%)$. These ones are the most widespread soils in Slovakia with various geological bedrock, often affected by the occurrence of geochemical anomalies with high to very high content of risk elements, including arsenic (mostly on crystalline and volcanic rocks). Therefore, the maximum values of As were determined in Cambisols in Slovakia. Regosols are characterised by the low content of As not only in topsoil but also in subsoil (3.37-3.30 mg.kg-1) (Tables 3, 4).

Table 4. Basic statistical indicators of As ( $\mathrm{mg}^{\left.-\mathrm{kg}^{-1}\right)}$ extracted with aqua regia in subsoil $(35-45 \mathrm{~cm})$ of the main soil types of Slovakia

\begin{tabular}{cccccccc}
\hline \multirow{2}{*}{ Soils } & \multicolumn{7}{c}{ Basic statistical indicators } \\
\cline { 2 - 8 } & $\mathrm{n}$ & $\mathrm{X}_{\min }$ & $\mathrm{X}_{\max }$ & $\mathrm{X}$ & median & $\mathrm{Sd}$ & $\mathrm{CV}(\%)$ \\
\hline 1 & 29 & 1.40 & 38.10 & 9.70 & 9.00 & 6.20 & 63.9 \\
\hline 2 & 31 & 2.96 & 15.60 & 9.13 & 8.83 & 2.79 & 30.53 \\
\hline 3 & 36 & 2.28 & 45.00 & 10.74 & 9.06 & 7.82 & 72.77 \\
\hline 4 & 89 & 1.51 & 100.00 & 12.55 & 9.82 & 14.51 & 115.57 \\
\hline 5 & 18 & 5.42 & 20.73 & 11.74 & 11.72 & 4.72 & 40.22 \\
\hline 6 & 8 & 0.77 & 7.68 & 3.30 & 3.19 & 2.10 & 63.73 \\
\hline
\end{tabular}

Explanations: 1 - Chernozems, 2 - Luvisols, 3 - Fluvisols, 4 - Cambisols, 5 - Rendzic Leptosols, 6 - Regosols, $\mathrm{n}$ - frequency, $\mathrm{X}_{\min }-$ minimum value, $\mathrm{X}_{\max }-$ maximum value, $\mathrm{X}-$ arithmetic mean, $\mathrm{Sd}$ - standard deviation, $\mathrm{CV}$ - coefficient of variation

These obtained values of As in soils of Slovakia are similar with the content of As in soils of Europe where an average content of As in topsoil is 7.03 mg.kg-1, whereas in subsoil - $6.02 \mathrm{mg} . \mathrm{kg}^{-1}$ (de Vos et al. 2006). The average content of As in non-contaminated soils of the world is $10 \mathrm{mg} \cdot \mathrm{kg}^{-1}$ (Berrow and Reaves 1984). Based on the obtained results in Slovakia, it may be said that 
the content of As is similar when compared with other non-contaminated soils in other countries (Boyle and Jonasson 1973, Kitagishi and Jamane 1981, Van Michelen et al. 1995, Adriano 2001, Eriksson 2001, Kabata-Pendias and Mukherjee 2007). As for the difference of As content between topsoil and subsoil, it is not significant in the main soil types of Slovakia (Fig. 2).

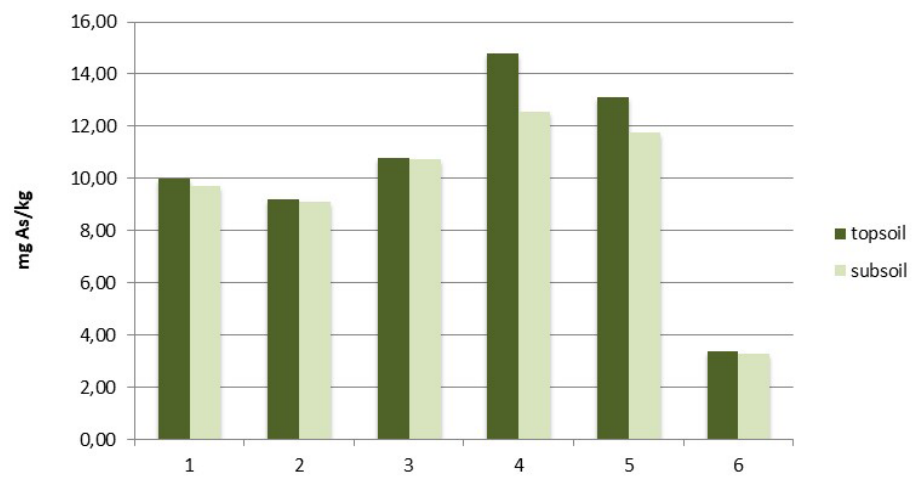

Fig. 2. Difference of As between topsoil $(0-10 \mathrm{~cm})$ and subsoil $(35-45 \mathrm{~cm})$ in the main soil types of Slovakia

Explanations: 1 - Chernozems, 2 - Luvisols, 3 - Fluvisols, 4 - Cambisols, 5 - Rendzic Leptosols, 6 - Regosols

A slight difference of As content between topsoil and subsoil was determined only in Cambisols and Rendzic Leptosols (FAO 2014) where the measured values of As are rather variable in all soil profiles which is characteristic of the mountainous and submountainous regions with varied mineralogical composition (mostly Arsenopyrite - FeAsS, Auripigment $-\mathrm{As}_{2} \mathrm{~S}_{3}$, Realgar - AsS) (Čurlík 2011, Zsolnai 2011). What is also interesting is the index of anthropogenic enrichment (Ex) - comparison of As concentration between topsoil and subsoil (Fig. 2). Calculated values of As in evaluated soils are even-tempered: for Chernozems 1.03, Luvisols 1.00, Fluvisols 1.00, Cambisols 1.18, Rendzic Leptosols 1.12 and Regosols 1.02. In general, it refers to a slight anthropogenic impact of As on agricultural soils of Slovakia.

However, the fact that the strong anthropogenic impact can affect the concentration of As in soil (e.g. combusting of fossil fuels, old mining activities, waste deposits from energetic industry, etc.) has only regional significance (Šimon 1997). One can mention here "hot-spots" regions. In this paper, they are presented on the example of the two main different regions affected by As (the Horná - Upper Nitra region - anthropogenic impact and the Stredný - Central Spiš region - mixed anthropogenic and geogenic impact). These regions are marked on the map of Slovakia (Fig. 1).

The Horná - Upper Nitra region is situated in the central part of Slovakia (Fig. 1) in the Hornonitrianska kotlina (basin) with an area of about $428 \mathrm{~km}^{2}$, 
built on neogene sediments bordered by volcanic (Vtáčnik and Kremnické vrchy) and by calcium carbonateous (Strážovské vrchy) mountains (Bobro and Hančul'ák 1997). The most widespread soils (FAO 2014) are Cambisols $(8,573$ ha $-41.8 \%$ of agricultural land of evaluated region), Retisols and Planosols (7,216 ha - 35.2\%), Fluvisols and gleyic Fluvisols (3,162 ha - 15.4\%) (Kobza et al. 2012). The main sources of As impact in this region is coal combusting, which is rich in arsenic (about 1,400 g As. $\mathrm{t}^{-1}$ ) (Verbich 1998), as well as electric and energetic industry (Kobza et al. 2012).

Basic statistical indicators of As in agricultural soils of the Horná - Upper Nitra region are given in Table 5. Mean values of As in topsoil and subsoil are lower than the valid hygienic limit for Slovakia (MPRV SR 2013). A higher value of As in topsoil can refer to an anthropogenic impact. The variability of As in topsoil (more in subsoil) is very high (coefficient of variation ranges from 152 to $213.1 \%$ ) (Table 5). This could be due to the various distribution of As in small area. Maximum values of As were determined on alluvial deposits along the Nitra river as a result of rupture of a gray ash dam in the surroundings of electric power caused by the storm in 1965 . As a result, As was washed away by the Nitra river stream to agricultural land, and very high content of As was found in agricultural soils. Distribution of agricultural soils, strongly affected by gray ash rich in As, often used for agricultural production, is shown in Figs. 3a, b. Buried ash grey layer occurs at the depth of 30-50 cm. The determined content of As in this layer is very high $-947 \mathrm{mg} . \mathrm{kg}^{-1}$ ! The content of As in topsoil is $202 \mathrm{mg} \cdot \mathrm{kg}^{-1}$, which is about $700 \%$ higher in this case in comparison with the valid hygienic limit for As in Slovakia (MPRV SR 2013)! According to Act 220/2004 on soil protection and land use (MPRV SR 2013), if the As hygienic limit (using aqua regia extraction) is exceeded in Slovakia, it is necessary to determine also bioavailable forms of As (extracted with $1 \mathrm{M} \mathrm{NH}_{4} \mathrm{NO}_{3}$ ) that may easily enter the plant and food chain, especially in case of acid soils. Based on our results, the content of bioavailable forms of As ranges between 0.016 and $0.997 \mathrm{mg} \cdot \mathrm{kg}^{-1}$ (hygienic limit for bioavailable forms of As in soil is $0.4 \mathrm{mg} . \mathrm{kg}^{-1}$ for Slovakia) (MPRV SR 2013). It turns out that the soils with the strong anthropogenic impact by As are sensitive also to the increased concentration of its bioavailable forms with potential risk for contamination of crop production and food chain, as well.

The Stredný - Central Spiš region is situated in the eastern part of Slovakia (Fig. 1), in the eastern part of the Slovak Ore Mountains (Slovenské rudohorie). This region is covered mostly by extensive grassland and forest. Cambisols are the dominant soil type, mostly on metamorphic rocks with the area of 1,552 ha ( $87 \%$ of agricultural land of evaluated region). The main sources of As in this region is metalurgy (anthropogenic impact) and the occurrence of geochemical anomalies (geogene - natural impact) (Petro 1991). 
Table 5. Basic statistical indicators of As $\left(\mathrm{mg}^{\mathrm{kg}} \mathrm{kg}^{-1}\right)$ extracted with aqua regia in agricultural soils of the Horná - Upper Nitra region

\begin{tabular}{|c|c|c|c|c|c|c|c|}
\hline \multirow{2}{*}{ Depth in $\mathrm{cm}$} & \multicolumn{7}{|c|}{ Basic statistical indicators } \\
\hline & $\mathrm{n}$ & $X_{\min }$ & $\mathrm{X}_{\max }$ & $\mathrm{X}$ & median & $\mathrm{Sd}$ & $\mathrm{CV}(\%)$ \\
\hline $0-10$ & 36 & 6.5 & 202.0 & 24.5 & 13.7 & 37.3 & 152.0 \\
\hline $34-45$ & 36 & 1.9 & 246.0 & 16.3 & 10.5 & 34.8 & 213.1 \\
\hline
\end{tabular}

Explanations: $\mathrm{n}$ - frequency, $\mathrm{X}_{\min }-$ minimum value, $\mathrm{X}_{\max }$ - maximum value, $\mathrm{X}$ - arithmetic mean, $\mathrm{Sd}$ - standard deviation, $\mathrm{CV}$ - coefficient of variation

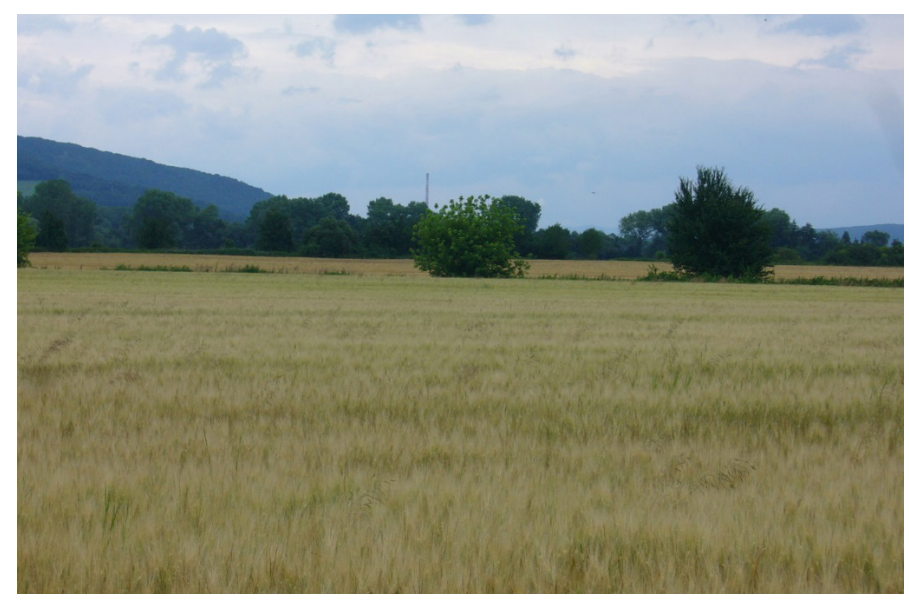

Fig. 3a. Agricultural land affected by arsenic in the Horná - Upper Nitra region

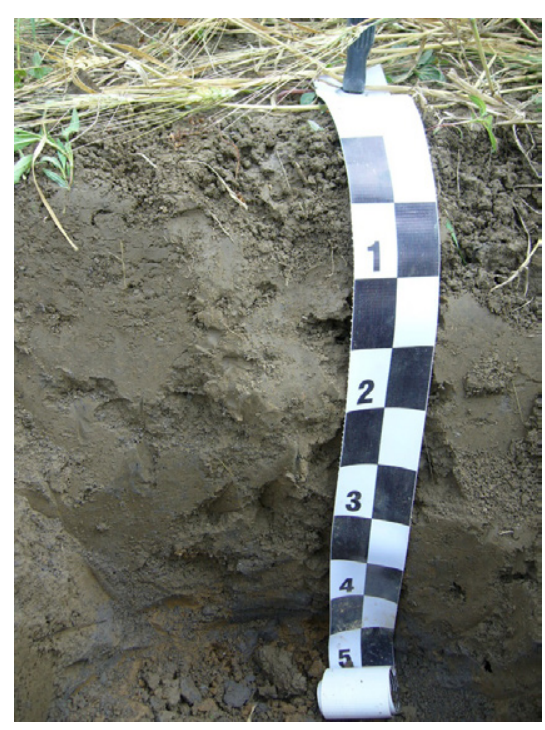

Fig. 3b. Occurrence of grey ash in the soil profile (at the depth of 30-50 cm) after the storm accident and destruction of waste deposit from energy industry in 1965 (Fluvisol) - Horná - Upper Nitra region (the same field above) 
Basic statistical indicators of As in agricultural soils of the Stredný - Central Spiš region are given in Table 6. Mean values of As are much higher in topsoil and subsoil than the valid hygienic limit for As (extracted with aqua regia) in Slovakia (25 mg. $\mathrm{kg}^{-1}$ for predominated sandy-loamy and loamy soils). Arsenic is more variable in subsoil (coefficient of variation is 143\%) (Table 6). It could be due to the heterogenous mineralogical composition of geochemical anomalies rich in As (Petro 1991) with anthropogenic inputs, mostly from industry. The whole evaluated agricultural region is covered by extensive grassland without arable land, particularly by abandoned agricultural land. Based on the obtained results, the area of As-contaminated agricultural soils (extracted with aqua regia) is 1,628 ha, i.e. $91 \%$ of the total area of agricultural land in the evaluated region (Kobza et al. 2019b).

Table 6. Basic statistical indicators of As $\left(\mathrm{mg} \cdot \mathrm{kg}^{-1}\right)$ extracted with aqua regia in agricultural soils of the Stredný - Central Spiš region

\begin{tabular}{cccccccc}
\hline \multirow{2}{*}{ Depth in cm } & \multicolumn{7}{c}{ Basic statistical indicators } \\
\cline { 2 - 8 } & $\mathrm{n}$ & $\mathrm{X}_{\min }$ & $\mathrm{X}_{\max }$ & $\mathrm{X}$ & median & $\mathrm{Sd}$ & $\mathrm{CV}(\%)$ \\
\hline $0-10$ & 14 & 16.6 & 259.0 & 129.5 & 121.0 & 85.5 & 66.0 \\
\hline $34-45$ & 14 & 17.0 & 533.0 & 101.5 & 52.4 & 145.2 & 143.0 \\
\hline
\end{tabular}

Explanations: $\mathrm{n}$ - frequency, $\mathrm{X}_{\min }$ - minimum value, $\mathrm{X}_{\max }$ - maximum value, $\mathrm{X}$ - arithmetic mean, $\mathrm{Sd}-$ standard deviation, $\mathrm{CV}$ - coefficient of variation

In addition, the content of bioavailable forms of As (extracted with $1 \mathrm{M}$ $\mathrm{NH}_{4} \mathrm{NO}_{3}$ ) in agricultural soils of the evaluated region varies in the range $0.013-$ $0.063 \mathrm{mg} \cdot \mathrm{kg}^{-1}$ (Kobza et al. 2019b) which is lower than the valid hygienic limit for bioavailable forms of As (0.4 mg. $\left.\mathrm{kg}^{-1}\right)$ in Slovakia (MPRV SR 2013).

\section{CONCLUSIONS}

The distribution of As in agricultural soils of Slovakia clearly reflects the parent material distribution affected often by the occurrence of geochemical anomalies with anthropogenic inputs (coal combusting, metalurgy, electrical and energetic industry, etc.). An average content of As (extracted with aqua regia) in agricultural soils of Slovakia is $10.16 \mathrm{mg} \cdot \mathrm{kg}^{-1}$ (low content). Evidently, low As contents are demonstrated in quartz eolic sands (Regosols) situated in the western part of the country. On the other hand, soils developed on acidic granitic and metamorphic rocks (mostly Cambisols) are typical with high to very high content of As.

Differences in As content between topsoil and subsoil are often evident. Anthropogenically affected soils have often higher content of As in topsoil, on the other hand, geogene-affected soils have often higher content of As in sub- 
soil. However, the soils affected by mixed - anthropogenic and geogene - factors are characterised by the high content of As in all soil profiles. Based on the research results, the content of bioavailable forms of As seems to be higher in case of anthropogenically-affected soils. There may be a risk of As transport, especially from acid soils into the plants and crop production as well as to the food chain. Finally, strongly contaminated soils can be recommended for the change of agricultural land use (e.g. for afforestation, resp. plantation of energetic trees - willow, poplar, paulownia, etc.).

\section{ACKNOWLEDGEMENT}

This research was financially supported by the project No. 471/2014 310/MPRV SR (Ministry of Agriculture and Rural Development of the Slovak Republic) and also by the Operational Programme Integrated Infrastructure within the project: "Scientific Support of Climate Change Adaptation in Agriculture and Mitigation of Soil Degradation" No. 313011W580, cofinanced by the European Regional Development Fund.

\section{REFERENCES}

[1] Adriano, D.C., 2001. Trace Elements in the Terestrial Environment. Springer-Verlag, New York-Berlin-Heidelberg, p. 866.

[2] Berghofer, R., Wilcke, W., Linkeš, V., Nestroy, O., Zech, W., 1997. Changes of Al and Heavy Metal Concentrations in Slovak Soils During the Last 25 Years. Journal of Plant Nutrition and Soil Science, 160(4): 469-474.

[3] Berrow, M.L., Burridge, J.C., 1980. Trace Elements Level in Soil: Effect of Sewage Sludge. In: Inorganic Pollution and Agriculture, pp. 159-190. MAFF Reference Book, No. 326, HMSO London.

[4] Berrow, M.L., Reaves, G.A., 1984. Background Levels of Trace Elements in Soils. Proceedings of the International Conference Environmental Contamination, London, July 1984, CEP Consultants Ltd. Edinburgh, pp. 333-340.

[5] Bobro, M., Hančulák, J., 1997. Mineralogical Properties of Imission Sedimens in the Areas of Magnesite Industry (in Slovak). Acta Montanistica Slovaca, 2(3): 240-243.

[6] Boyle, R.W., Jonasson, I.R., 1973. The Geochemistry of Arsenic and Its Use as an Indicator Element in Geochemical Prospecting. Journal of Geochemical Exploration, 2: 251-296.

[7] Čurlík, J., Šefčík, P., 1999. Geochemical Atlas of the Slovak Republic. Part V: Soils (in Slovak). MŽPSR, VÚPOP, Bratislava, p. 99.

[8] Čurlík, J., 2004. Map of Soil Contamination of Horná - Upper Nitra Region in the Scale 1:50 000. ŠGÚDŠ Bratislava, p. 85.

[9] Čurlík, J., 2011. Potential Toxic Trace Elements and Their Distribution in Soils of Slovakia (in Slovak). PFUK Bratislava, p. 462.

[10] De Vos, W., Tarvainen, T., Salminen, R., Reeder, J.A., De Vivo, B., Dementriades, A., Pirč, S., Batista, M.J., Marsina, K., Ottesen, R., O’Connoor, P.J., Bidovec, M., Lima, A., Siewers, V., Taylor, H., Shaw, R., Salpeteur, I., Gregorauskiene, V., Halamic, J., Slaninka, I., Lax, K., Gravesen, P., Birke, M., Breward, N., Ander, E.L., Jordan, G., Duriš, M., Klein, P., Pasieczna, 
A., Lis, J., Mazreku, A., Gilucis, A., Heitzman, P., Klaver, G., Petersell, V., 2006. Geochemical Atlas of Europe, Part 2: Interpretation of Geochemical Maps.

[11] Eriksson, J.E., 2001. Concentration of 61 Trace Elements in Sewage Sludge, Farmyard Manure, Mineral Fertilizers, Precipitation and in Oil And Crops. Swedish EPA, Rep. 5159, Stockholm.

[12] FAO, 2014. World Reference Base (WRB), FAO Rome, p. 203.

[13] Fergusson, J.E., 1990. The Heavy Elements. Chemistry, Environmental Impact and Health Effects. Pergamon, Press, p. 614.

[14] Kabata-Pendias, A., Pendias, H., 1992. Trace Elements in Soils and Plants. CRC Press London, $2^{\text {nd }}$ ed., p. 365.

[15] Kabata-Pendias, A., Mukherjee, D., 2007. Trace Elements From Soil to Human. Springer-Verlag, Berlin-Heidelberg, p. 561.

[16] Kabir, M.S., Salam, M.A., Paul, D.N.R., Hossain, M.I., Rahman, N.M.F., Aziz, A., Latif, M.A., 2016. Spatial variation of arsenic in Soil, Irrigation Water and Plant Parts: A Microlevel Study. The Scientific World Journal, article ID 2186069, p. 14. https://doi. org/10.1155/2016/2186069.

[17] Kitagishi, K., Jamane, I., 1981. Heavy Metal Pollution in Soils of Japan. Japan Scientific Societes Press, Tokyo, p. 301.

[18] Kobza, J., Bezák, P., Hrivňáková, K., Medved’, M., Náčiniaková, Z., 2007. Criteria for Identification of Risk Polluted Areas of Agricultural Land and Methodological Procedures of Their Evaluation (in Slovak). VUPOP, Bratislava, pp. 26-32.

[19] Kobza, J., 2011. Actual Content of Arsenic on Agricultural Soils of Slovakia - Its Sources and Behaviour (in Slovak). In: Proceedings of Soil Science and Conservation Research Institute, No. 33, Bratislava, pp. 86-94.

[20] Kobza, J., Hrivňáková, K., Makovníková, J., Barančíková, G., Bezák, P., Bezáková, Z., Dodok, R., Grečo, V., Chlpík, J., Lištjak, M., Mališ, J., Pí̌s, V., Schlosserová, J., Slávik, O., Styk, J., Širáň, M., 2011. Unified Analytical Procedures in Soil (in Slovak). VUPOP, Bratislava, p. 136.

[21] Kobza, J., Barančíková, G., Makovníková, J., Pálka, B., Styk, J., Širáň, M., 2012. Complexed Evaluation of Current State of Sensitive Region of Horná - Upper Nitra and Surroundings with Impact on Solution of Soil Protection Measures (in Slovak). National Agricultural and Food Centre - Soil Science and Conservation Research Institute, Bratislava, p. 82.

[22] Kobza, J., Barančíková, G., Dodok, R., Makovníková, J., Pálka, B., Styk, J., Širáň, M., 2019a. Current State and Development of Monitoring Soil Properties as a Basis to Their Protection and Next Land Use (Years 2013-2017) (in Slovak). National Agricultural and Food Centre - Soil Science and Conservation Research Insitute, Bratislava, p. 252.

[23] Kobza, J., Barančíková, G., Makovníková, J., Pálka, B., Styk, J., Širáň, M., 2019b. Complexed Evaluation of Current State of Sensitive Region of Krompachy-Rudñany and Surroundings with Impact on Solution of Soil Protection Measures (in Slovak). National Agricultural and Food Centre - Soil Science and Conservation Research Insitute, Bratislava, p. 75.

[24] Melicherčík, M., Melicherčíková, D., 2010. Influence of Environment and Effects of Substances on the Human Body (in Slovak). FPV UMB, Banská Bystrica, p. 345.

[25] MPSR (Ministry of Agriculture of the Slovak Republic), 2004. Act No. 220/2004 on protection and agricultural land use from 28.4.2004 (in Slovak), Bratislava, pp. 2278-2315.

[26] MPRV SR (Ministry of Agriculture and Rural Development of the Slovak Republic), 2013. Regulation of MPRV SR, No. 59/2013. Limit values of risk elements (in Slovak). Bratislava, p. 570.

[27] Petro, M., 1991. Accompanying Report to the Map of Geochemical Anomalies in Slovakia in the Scale 1:200 000 (in Slovak). Banská Bystrica.

[28] Shacklette, H.T., Boerngen, J.G., 1984. Elements Concentrations in Soils and Other Surficial Materials of the Conterminous United States. U.S. Geological Survey Professional Paper 1270, p. 105. 
[29] Smith, S.E., Najdu, R., Alston, A.M., 1998. Arsenic in Soil Environment: A Review. Advances in Agronomy, 64: 149-195.

[30] Šimon, L., 1997. Explanations to Geological Map of Vtáčnik Mountains and Hornonitrianska kotlina (basin) 1:50 000 (in Slovak). GS SR, Bratislava, p. 281.

[31] Van Mechelen, L., Groenemans, R., Van Rast-Martens, K., 1995. Current Background Values for Heavy Metals and Arsenic in Flanders. Vol. 11, L.H. Ahrens (Ed.), Pergamon Press, p. 791.

[32] Verbich, F., 1998. Evaluation of Geochemical and Mineralogical Properties of Coal Deposit in Nováky (in Slovak). Acta Montanistica Slovaca, 3(3): 378-383.

[33] Wilcke, W., Krauss, M., Kobza, J., 2005. Concentrations and Forms of Heavy Metals in Slovak Soils. Journal of Plant Nutrition and Soil Science, 168: 676-686.

[34] Zsolnai, S., 2011. Behaviour of Arsenic in Soil with Regard to Sources of Its Occurrence (in Slovak). Diploma thesis, FPV-UMB, Banská Bystrica, p. 95. 